\title{
TECNOLOGIA DE TRADUÇÃO E SEU ENSINO
}

\author{
Érika Nogueira de Andrade Stupiello*
}

PYM, A., PEREKRESTENKO, A., STARINK, B. (2006) Translation technology and its teaching.Tarragona, Espanha. Disponivel em http://isg.urv.es/publicity/isg/ publications/technology_2006/idex.htm. Acesso em 22/ 06/2006

O progresso tecnológico experimentado em nossa era tem provocado diversas mudanças na maneira como vivemos e interagimos com as pessoas e o mundo à nossa volta. Velocidade e facilidade de acesso a informações, e de troca das mesmas, são conveniências características da globalização e, em grande parte, responsáveis pelo considerável impulso observado no comércio de produtos, serviços e informações entre povos de diferentes nacionalidades. A demanda por respostas rápidas às informações recebidas por meios eletrônicos tem estimulado a progressiva substituição de materiais impressos por documentos digitalizados, de edição mais eficaz e de transmissão mais rápida ou de ágil compilação e armazenamento em banco de dados. Se, por um lado, a internet tem propiciado acesso irrestrito a informações e promovido contatos mais rápidos e eficazes entre pessoas e empresas, por outro, ela promove a ilusão de que as diferenças lingüísticas possam ser facilmente resolvidas pela tradução.

Segundo Anthony Pym, Alexander Perekrestenko e Bram Starink, organizadores do livro Translation tecnhology and its

Doutoranda em Estudos Lingüísticos pela Unesp de São José do Rio Preto. Coordenadora e docente do curso de Bacharelado em Letras com Habilitação em Tradutor e Intérprete em Língua Inglesa da União das Faculdades dos Grandes Lagos - Unilago, de São José do Rio Preto/SP. 
teaching ("Tecnologia de tradução e seu ensino"), nunca houve uma demanda tão acirrada por traduções nas mais diversas línguas, traduções essas que não deixam de requerer conhecimento lingüístico, mas já não podem ser consideradas "meras traduções", desde que envolvidas com as tecnologias de tradução. Conforme explicam no prefácio do livro, o qual, aliás, já incorpora as mudanças que são discutidas na obra acerca do status do texto impresso, por exemplo, ao disponibilizar a mesma em formato digital (extensão pdf), a demanda atual por serviços de tradução envolve tanto conhecimento de línguas, como competência na manipulação de programas de memórias de tradução, em gerenciamento de terminologia e conteúdo e, cada vez mais, na integração de várias formas de tradução automática e semi-automática.

Em face à mudança da concepção sobre a tradução, muitas instituições que se dedicam ao ensino dessa disciplina têm refletido sobre as inevitáveis mudanças a que seus currículos terão de se submeter a fim de atender às solicitações de seus aprendizes de tradução, qualificando-os para a prática profissional. Nesta obra sobre a qual ora refletimos, tais mudanças são abordadas pelas perspectivas da pedagogia e da prática, delineadas por artigos resultantes de várias atividades desenvolvidas pelo Grupo de Estudos Interculturais da Universitat Rovira e Virgili, em Terragona, Espanha. Esses artigos estão distribuídos em três seções.

A primeira delas apresenta um histórico da tecnologia de tradução e é encabeçada por um artigo de José Ramon Biau Gil e Anthony Pym, os quais constroem um panorama dos progressos alcançados pelas novas ferramentas computacionais de tradução e do impulso por elas proporcionado em termos de eficiência de comunicação com clientes e colegas, além de agilidade de trabalho. Conforme argumentam, se, por um lado, programas de memórias de tradução propiciam ganhos consideráveis em recuperação de traduções já realizadas e no compartilhamento de dados, por outro, ainda requerem investimento considerável por parte do tradutor, bem como a disponibilidade de tempo para o treinamento e domínio dessas novas tecnologias. Essa é uma realidade geralmente ignorada por clientes que, cada vez 
mais, esperam que o tradutor já tenha familiaridade com certas ferramentas na realização de suas traduções, uma habilidade que se demonstra, então, um requisito decisivo na contratação de serviços.

Os autores chamam a atenção para a própria característica de muitos dos textos traduzidos nos dias de hoje que, conforme demonstram, apresentam delimitação cada vez mais imprecisa, uma vez que, em formato digital, são passíveis de constante revisão e alteração, o que pode distanciar muito o tradutor do formato final que o material por ele traduzido tomará. Por outro lado, salientam que, embora o tradutor esteja, por vezes, muito distante de seu cliente final, a "tradução ainda é um serviço que depende de um alto grau de confiança entre o tradutor e o cliente". Esse aspecto parece interessante ao tomarmos que, embora a tecnologia torne possivel que um tradutor, atuante numa cidade distante dos grandes centros, tenha acesso a clientes e empresas multinacionais em qualquer parte do mundo; e mais: não o restrinja à competição, em condições de igualdade, com tradutores estabelecidos em grandes metrópoles, os recursos por ela disponibilizados não são suficientes para que este profissional se estabeleça no mercado de trabalho. Da mesma forma que a implementação de novas tecnologias é imprescindível ao tradutor, não se pode menosprezar a relação de confiança entre o profissional e o cliente.

Os dois outros artigos incluídos na primeira parte do livro tratam da localização, uma prática que envolve a tradução e a adaptação de softwares para novos mercados. Bert Essenlink, em "The Evolution of Localization", faz um retrospecto da indústria da localização que, com a introdução dos microcomputadores no início dos anos oitenta, experimentou considerável crescimento com a rápida expansão comercial de produtos de informática norte-americanos em mercados internacionais. A própria mudança de foco mercadológico teria levado muitos fabricantes a buscar meios de adaptar seus produtos aos padrões, aos hábitos e às línguas locais, o que passou a exigir o desenvolvimento de habilidades técnicas para a realização de tais tarefas. Soma-se a isso a necessidade de sofisticado conhecimento lingüístico e cultural de tradutores dispostos a atuar nesse promissor mercado. 
Se o desenvolvimento dessas novas habilidades era promovido pelas próprias indústrias no início, a localização, mais tarde, passou a atrair o interesse, ainda que restrito, de algumas instituições acadêmicas nos Estados Unidos e na Europa. Essas instituições passaram, a partir dos anos noventa, a oferecer programas e cursos sobre localização, conforme revela Tim Altanero em "The localization job market in academe".

Aliás, segundo Pym, pelo fato de a localização ser institucionalmente vista como mais "um nome elegante para o ato de adaptar um texto para um público leitor específico, algo que os tradutores fazem há milênios", o espaço que ocupa nos departamentos dos poucos cursos de tradução ainda é limitado. Seu ensino é, na maioria das vezes, exercido por docentes que não começaram trabalhando com localização e, pelo fato de a prática não ter ainda constituído objeto sistemático de estudo, ainda não conta com publicações que possam descrever e, talvez, orientar o rumo que a área possa vir a tomar.

De uma maneira também inusitada, a segunda seção de Translation technology and its teaching, intitulada "Localization and translation training (an online conference)" traz as respostas às questões sobre treinamento em localização discutidas em uma conferência on-line por professores de universidades na Irlanda, no Reino Unido e no Canadá. Todos os participantes reconhecem que os materiais traduzidos atualmente pouco se assemelham aos textos traduzidos no início dos anos noventa, e que a localização estaria muito mais associada à globalização do que à tradução, sendo vista como uma resposta à necessidade das empresas de adaptar seus produtos às particularidades dos mercados internacionais. Vê-se, também, como essencial que a localização passe a integrar os currículos dos cursos de formação de tradutores, embora se reconheça que a qualificação desses aprendizes muito provavelmente deverá ser conduzida por profissionais atuantes no mercado de localização e que não necessariamente compõem o quadro docente da maioria das universidades que oferecem cursos de tradução.

Por fim, a terceira seção, denominada "Technology and Translation", reúne seis artigos contemplando, de maneira mais pontual, o treinamento de tradutores nas tecnologias de localização e memórias de tradução. 
Ignacio Garcia, da University of Western Sydney, na Austrália, questiona se as memórias de tradução constituíram uma "benção ou uma maldição" para o trabalho do tradutor. Se, por um lado, tradutores que utilizam diferentes programas de memórias de tradução atestam ganhos em produtividade, com o acesso rápido a soluções já encontradas para suas traduções, eliminando-se o retrabalho, por outro, vivenciam uma situação peculiar às tecnologias adotadas: a solicitação de clientes para reduzirem-se os custos de traduções que contenham segmentos já traduzidos, integrando os bancos de dados das memórias fornecidos pelos próprios clientes, ou a solicitação sobre aquelas que resultem de serviços anteriormente realizados para esses mesmos clientes, serviços esses já remunerados.

Pode-se argumentar que esse cenário suscita questões de natureza ética em, pelo menos, dois aspectos: quando se estabelece um valor para um serviço de tradução, deve-se considerar que o contratante terá direito, também, ao banco de dados formado a partir da tradução para ele realizada? E, por extensão, o tradutor que faz uso do banco de dados previamente fornecido por um cliente pode afirmar que a tradução que realizou é realmente sua? Essas são apenas duas das várias questões que devem gerar bastante discussão acerca do impacto das tecnologias nas relações entre tradutores e potenciais clientes.

Uma conclusão a que se pode chegar com a leitura do livro ora resenhado é a de que a tecnologia não é mais uma opção nos dias de hoje; antes, é indissociável de qualquer trabalho de tradução. Se, a princípio, experimentou-se com os avanços tecnológicos um temor ingênuo de que a automação levaria à substituição do tradutor, hoje tem-se por indispensável a atuação do tradutor humano em projetos sérios, que envolvam um certo grau de automação na produção de traduções. Uma das maiores contribuições deste livro é apresentar, por diversas perspectivas, o que há de mais moderno a ser empregado pelo tradutor em seu trabalho. Serve também como ponto de partida para uma reflexão mais detalhada sobre os limites e os conflitos da coexistência entre o homem e a máquina, especialmente quando se trata de assumir a responsabilidade sobre a produção do novo significado que o texto traduzido passará a ter. 